\title{
Mutation screening of the thyroid peroxidase gene in a cohort of 55 Portuguese patients with congenital hypothyroidism
}

\author{
Carina Rodrigues, Paula Jorge, José Pires Soares ${ }^{1}$, Isaura Santos ${ }^{3}$, Regina Salomão ${ }^{3}$, Manuela Madeira ${ }^{3}$, \\ Rui Vaz Osório ${ }^{2}$ and Rosário Santos \\ Unidade de Genética Molecular, ${ }^{1}$ Unidade de Consulta and ${ }^{2}$ Comissão Nacional de Diagnóstico Precoce, Instituto de Genética Médica Jacinto Magalhães, \\ Praça Pedro Nunes 88, 4099-028 Porto, Portugal and ${ }^{3}$ Consulta de Endocrinologia Pediátrica, Hospital de Santa Maria, Av. Prof. Egas Moniz, \\ 1699 Lisboa Codex, Portugal \\ (Correspondence should be addressed to R Santos; Email: rosario.santos@igm.min-saude.pt)
}

\begin{abstract}
Objective: Defects in the human thyroid peroxidase (TPO) gene are reported to be one of the causes of congenital hypothyroidism $(\mathrm{CH})$ due to a total iodide organification defect. The aim of the present study was to determine the nature and frequency of TPO gene mutations in patients with $\mathrm{CH}$, characterised by elevated TSH levels and orthotopic thyroid gland, identified in the Portuguese National Neonatal Screening Programme.

Subjects and methods: The sample comprised 55 patients, from 53 unrelated families, with follow-up in the endocrinology clinics of the treatment centres of Porto and Lisbon. Mutation screening in the TPO gene (exons 1-17) was performed by single-strand conformational analysis followed by sequencing of fragments with abnormal migration patterns.

Results: Eight different mutations were detected in 13 patients (seven homozygotes and six compound heterozygotes). Novel mutations included three missense mutations, namely 391T $>\mathrm{C}$ (S131P), $1274 \mathrm{~A}>\mathrm{G}(\mathrm{N} 425 \mathrm{~S})$ and $2512 \mathrm{~T}>\mathrm{A}(\mathrm{C} 838 \mathrm{~S})$, as well as the predictable splice mutation 2748G > A (Q916Q/spl?). The undocumented polymorphism 180-47A $>\mathrm{C}$ was also detected. Conclusion: The results are in accordance with previous observations confirming the genetic heterogeneity of TPO defects. The proportion of patients in which the aetiology was determined justifies the implementation of this molecular testing in our $\mathrm{CH}$ patients with dyshormonogenesis.
\end{abstract}

European Journal of Endocrinology 152 193-198

\section{Introduction}

The latest annual report by the committee of the Portuguese National Neonatal Screening Programme indicates that the incidence of congenital hypothyroidism (CH) in Portugal is approximately 1/3238 newborns (1). Prior to the implementation of this screening programme (presently with a coverage rate of around $99.5 \%), \mathrm{CH}$ was one of the most frequent causes of mental retardation in children. $\mathrm{CH}$ includes different clinical entities and, in the majority of cases, is a consequence of thyroid dysgenesis, in which the gland is either absent (thyroid agenesis) or located ectopically and/or severely reduced in size (hypoplasia). It is estimated that $15 \%$ of $\mathrm{CH}$ cases occur as a consequence of defects in the biochemical mechanisms responsible for thyroid hormone biosynthesis (thyroid dyshormonogenesis) in which human thyroid peroxidase (TPO) plays an essential role (2). Many patients with total iodide organification defect have been shown to have mutations in the TPO gene (3-15). TPO is a membrane-linked haemoprotein located at the apical membrane of the thyroid cells; it catalyses the iodination and subsequent coupling of tyrosine residues in thyroglobulin, resulting in the synthesis of the thyroid hormones tri-iodothyronine and thyroxine (T4). The human TPO gene is located on chromosome 2p25 (16) and consists of 17 exons that span $150 \mathrm{~kb}$, while the respective full-length mRNA is about $3 \mathrm{~kb}$ long (17). Other genes thought to be implicated in this form of $\mathrm{CH}$ include the thyroglobulin (TG) gene (2), the sodium symporter (NIS) gene (18), the pendrin gene $(P D S)(19)$ and, more recently, thyroid oxidase gene 2 (THOX2) (20). In the present study, we screened for TPO gene mutations in $55 \mathrm{CH}$ patients presenting elevated thyroid-stimulating hormone (TSH) levels and orthotopic thyroid gland.

\section{Subjects and methods}

\section{Patients}

Since the implementation of the National Neonatal Screening Programme in Portugal, 723 cases of $\mathrm{CH}$ have been detected (1). Diagnosis of $\mathrm{CH}$ is based on

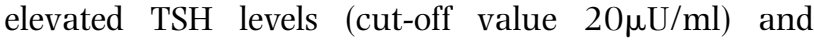


decreased T4 levels (normal $>6.5 \mu \mathrm{g} / \mathrm{dl}$ ), ascertained in heel puncture blood samples collected on S\&S 903 filter paper (Schleicher and Schuell GmbH, Dassel, Germany) between the 4th and 7th day of life. Mutation screening was performed on a group of $\mathrm{CH}$ patients with elevated TSH levels at the time of diagnosis and orthotopic thyroid gland. The perchlorate discharge test, which aids in the recognition of iodide organification defects, is not routinely performed; as such, elevated plasma Tg concentrations were also considered in the selection of patients, so as to exclude cases likely to result from defects in $\mathrm{Tg}$ synthesis or TSH receptor inactivation. The selected 55 patients were members of 53 apparently unrelated families, none of whom had any knowledge of consanguinity. Informed consent was obtained from the patients or, in the case of minors, from their parents.

\section{Genomic analysis}

DNA was isolated from peripheral blood according to the salting out method (21). The 17 exonic regions of the TPO gene were amplified by PCR with primers as described previously (5). The PCR reaction mixture contained $25 \mu \mathrm{l}$ of a $2 \times$ PCR master mix (Promega Corporation, Madison, WI, USA), 1 pmol each of forward and reverse primers, $1 \mu \mathrm{l}$ genomic DNA (50$250 \mathrm{ng}$ ) and nuclease-free water to a final volume of $50 \mu \mathrm{l}$. The PCR reactions were performed in a 9600 thermal cycler (Applied Biosystems, Foster City, CA, USA) with an initial denaturation step of $10 \mathrm{~min}$ at $94^{\circ} \mathrm{C}$, followed by 35 cycles consisting of denaturation at $94^{\circ} \mathrm{C}$ for $1 \mathrm{~min}$, annealing at $57^{\circ} \mathrm{C}$ for $1 \mathrm{~min}$ and extension at $72^{\circ} \mathrm{C}$ for $1 \mathrm{~min}$, and with a final extension at $72{ }^{\circ} \mathrm{C}$ for $10 \mathrm{~min}$. The 18 amplicons (exon 8 subdivided into two fragments, $8 \mathrm{~A}$ and $8 \mathrm{~B}$ ) were subjected to single-strand conformational analysis (SSCA) using both the PhastSystem (Pharmacia Biotech) in PhastGels, according to the manufacturer's instructions, and a standard vertical electrophoresis system, on $0.5 \times$ and $1.0 \times$ MDE gels (FMC Bioproducts, Rockland, ME, USA). Gels were stained by standard silver staining methods. Fragments presenting abnormal electrophoretic mobility were sequenced using the Big Dye Terminator Kit v2.0 (Applied Biosystems) and capillary electrophoresis. Because of poor electrophoretic separation on SSCA, some fragments $(8 \mathrm{~A}, 8 \mathrm{~B}$ and 11) were also sequenced in all patients. A novel mutation identified in exon 8 was further characterised by restriction analysis. This mutation creates a new restriction site for DdeI. The PCR product of fragment 8B was incubated with DdeI (New England BioLabs, Beverly, MA, USA) overnight at $37^{\circ} \mathrm{C}$ and separated on a $2 \%$ agarose gel.

\section{Population studies}

To investigate whether an alteration was a causal mutation or a common polymorphic variant, population screens were carried out on 100 healthy controls, either by SSCA or by differential restriction analysis. Family co-segregation studies were performed whenever possible.

\section{Data analysis}

The novel predicted splice site mutation, 2748G $>$ A, was run on the GENSCAN program which predicts the locations and exon-intron structures of genes (http://genes.mit.edu/GENSCAN.html). For the novel missense mutations, phylogenetic conservation of the amino acid sequences among the peroxidase superfamily was assessed with the aid of the CLUSTAL program (http://www.ebi.ac.uk/servicestmp/clustalw).

\section{Results and discussion}

\section{Mutation analysis of the TPO gene}

In all, eight different mutations and 15 polymorphisms were detected in this group of patients. Novel alterations included three missense and one putative splice mutation, as well as a silent $\mathrm{A}$ to $\mathrm{C}$ transversion in intron 3 (180-47A > C). In 13 of the 55 patients, deleterious mutations were identified in both alleles. Clinicopathologic and mutation data are summarised in Tables 1 and 2. Sequence analysis of exon 8 revealed a homozygous GGCC duplication at nucleotide position 1187 in two unrelated patients (1a and 2a). This mutation has been described previously (3) and leads to a frameshift with a termination signal in exon 9. The same duplication (1183_1186dupGGCC) was also found in the affected siblings of family 3 , in heterozygosity with $1978 \mathrm{C}>\mathrm{G}$, a documented missense mutation in exon 11 which results in a glutamine to glutamic acid substitution at amino acid position 660 (Q660E) (10). Further investigation in other members of the family revealed that the father carried the 1183_1186dupGGCC mutation, while the mother and four unaffected sisters were carriers of the Q660E mutation. The patient in family 4 was found to be heterozygous for Q660E and a novel missense mutation in exon 8, where an A to G transition at nucleotide position 1274 results in an aspargine to serine change at codon 425 (Fig. 1). This alteration creates a new restriction site for DdeI, such that the $480 \mathrm{bp}$ amplicon encompassing exon 8 is cut into fragments of 322 and 158 bp (Fig. 1C). Restriction analysis with DdeI was thus used to screen 100 healthy controls, none of whom presented this base change. Only the patient's mother was available for sequence analysis, and she was found to carry the new N425S mutation. SSCA of exon 9 revealed an aberrant conformer in patient 5a. Both parents were heterozygous for this abnormal fragment, while an unaffected sister presented only the normal migration pattern. Sequence analysis showed a homozygous, known missense mutation at 
Table 1 Clinicopathological characteristics of the $\mathrm{CH}$ patients (ten families) with TPO mutations identified in this study.

\begin{tabular}{|c|c|c|c|c|c|c|c|}
\hline $\begin{array}{l}\text { Family/ } \\
\text { patient }\end{array}$ & Sex & $\begin{array}{c}\text { Current age } \\
\text { (years) }\end{array}$ & Thyroid gland & $\begin{array}{c}\text { TSH* }^{\star} \\
(\mu \mathrm{U} / \mathrm{ml})\end{array}$ & $\begin{array}{c}\mathbf{T 4}^{\star} \\
(\mu \mathrm{g} / \mathrm{dl})\end{array}$ & $\underset{(\mathrm{ng} / \mathrm{ml})}{\mathbf{T g}}$ & Identified mutations \\
\hline $1 / a$ & $\mathrm{~F}$ & 7 & Goiter & 215 & 0.7 & 299 & [1183_1186dupGGCC] $+\left[1183 \_1186\right.$ dupGGCC] \\
\hline 2/a & $\mathrm{F}$ & 2 & Goiter & 195 & 2.9 & 955 & [1183_1186dupGGCC] + [1183_1186dupGGCC] \\
\hline $3 / a$ & $\mathrm{~F}$ & 32 & Goiter & ND & ND & ND & {$\left[1183 \_1186\right.$ dupGGCC $]+[1978 \mathrm{C}>\mathrm{G}]$} \\
\hline $3 / b$ & $\mathrm{~F}$ & 13 & Goiter & 235 & 1.9 & 79.7 & [1183_1186dupGGCC $]+[1978 \mathrm{C}>\mathrm{G}]$ \\
\hline 4/a & $\mathrm{F}$ & 19 & Goiter & 81 & 3.6 & ND & {$[1274 \mathrm{~A}>\mathrm{G}]+[1978 \mathrm{C}>\mathrm{G}]$} \\
\hline 5/a & M & 11 & Goiter & 109.6 & 1.2 & 1344 & {$[1477 G>A]+[1477 G>A]$} \\
\hline $6 / a$ & $\mathrm{~F}$ & 5 & Goiter & 285 & 2.8 & 731 & {$[1978 C>G]+[1978 C>G]$} \\
\hline 7/a & $\mathrm{F}$ & 18 & Goiter & 192 & 0.6 & ND & {$[2422$ delT] $+[2422$ delT] } \\
\hline $8 / a$ & M & 3 & Goiter & 258 & 0.5 & 416 & {$[2422 \mathrm{delT}]+[391 \mathrm{~T}>\mathrm{C}]$} \\
\hline $9 / a$ & M & 5 & Goiter & 328 & 2.9 & 2356 & {$[2512 \mathrm{~T}>\mathrm{A}]+[2512 \mathrm{~T}>\mathrm{A}]$} \\
\hline $9 / b$ & M & 3 & Goiter & 378 & 1.8 & 1758 & {$[2512 T>A]+[2512 T>A]$} \\
\hline $10 / a$ & $\mathrm{~F}$ & 7 & Normal & 288 & 0.7 & 640 & {$[1978 C>G]+[2748 G>A]$} \\
\hline \multirow[t]{2}{*}{$10 / b$} & $\mathrm{~F}$ & 3 & Normal & 35.8 & 3.7 & ND & {$[1978 C>G]+[2748 G>A]$} \\
\hline & & & Normal values & $<20$ & $6.5-17$ & $3-52$ & \\
\hline
\end{tabular}

* The levels of T4 and TSH at the 4th-7th day of life.

ND, not determined.

Table 2 Description of TPO mutations in the $13 \mathrm{CH}$ patients.

\begin{tabular}{|c|c|c|c|c|}
\hline Exon & Mutation $^{\mathrm{a}}$ & $\begin{array}{l}\text { Effect of the mutation } \\
\text { on protein synthesis }\end{array}$ & Reference & Frequency of mutant alleles ${ }^{b}$ \\
\hline 5 & $391 \mathrm{~T}>\mathrm{C}$ & S131P & Present study & $1 / 110$ \\
\hline 8 & 1183_1186dupGGCC & N396fsX76 & 3 & $6 / 110$ \\
\hline 8 & $1274 \bar{A}>G$ & N425S & Present study & $1 / 110$ \\
\hline 9 & $1477 \mathrm{G}>\mathrm{A}$ & G493S & 15 & $2 / 110$ \\
\hline 11 & $1978 C>G$ & Q660E & 10 & $7 / 110$ \\
\hline 14 & 2422delT & C808fsX23 & 11 & $3 / 110$ \\
\hline 14 & $2512 T>A$ & C838S & Present study & $4 / 110$ \\
\hline 16 & $2748 G>A$ & Spl? & Present study & $1 / 110$ \\
\hline
\end{tabular}

${ }^{\text {a }}$ The first $A$ in the TPO start codon considered as position 1.

${ }^{\mathrm{b}}$ Frequency amongst the 55 patients (110 alleles).

position 1477 with a nucleotide change from $\mathrm{G}$ to $\mathrm{A}$, resulting in a glycine to serine substitution at codon 493. Patient 6a was homozygous for the documented mutation Q660E that is also present in compound heterozygosity in the affected siblings of families 3 and 10.

In the patient of family 7 , a mobility shift in exon 14 led to the identification of homozygosity for the known single base pair deletion 2422delT (11). This frameshift mutation, which results in a premature stop codon, was found in heterozygosity in both parents and in one of two unaffected brothers. Patient 8a was also heterozygous for this frameshift mutation and the novel mutation in exon 5: a $\mathrm{T}$ to $\mathrm{C}$ transition at nucleotide 391 that replaces a serine at codon 131 with a proline (S131P). Both affected siblings of family 9 were found to be homozygous for a novel missense mutation in exon 14: a T to A transition at nucleotide 2512, resulting in a cysteine to serine substitution at codon 838 (C838S). The parents were heterozygous for this mutation. Finally, two other affected siblings (family 10) were found to be compound heterozygotes for Q660E and a novel point mutation, 2748G $>$ A, in exon 16 (Fig. 2). This novel mutation, silent at the amino acid level (Q916Q), was located at position -1 of the $5^{\prime}$ (donor) splice site consensus sequence in exon 16 and thus putatively affects splicing. The father is a carrier of this novel mutation in exon 16 and the mother carries the known mutation in exon 11.

\section{Deleterious effect of the novel identified mutations}

No thyroid tissue was available for the functional studies of the peroxidases with the four novel mutations. The deleterious effect of the missense mutations was therefore evaluated by assessing the degree of evolutionary conservation of the respective amino acids, among several human and other animal wild-type peroxidases (Table 3). This approach of multiple sequence alignment indicated that $\mathrm{N}^{425}$ and some neighbouring residues are well conserved among the peroxidase superfamily. $\mathrm{C}^{838}$ is similarly well conserved among the TPOs of different species but has no counterpart in human mieloperoxidase (MPO), lactoperoxidase (LPO) or eosinofil peroxidase (EPO), or in bovine lactoperoxidase. The region 
$\mathbf{A}$

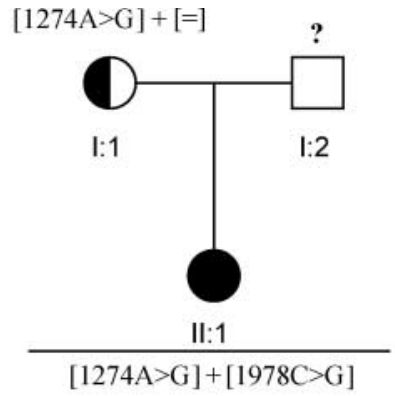

B
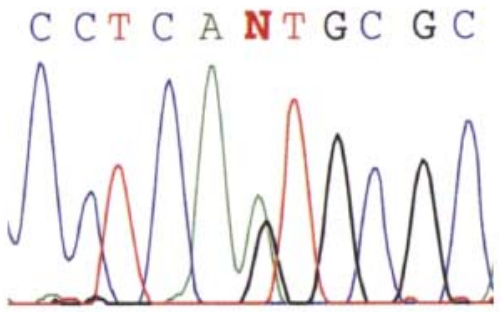

C
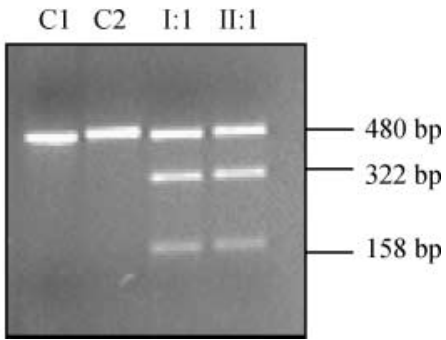

Figure 1 Novel heterozygous mutation in exon 8 (1274A > G) found in patient $4 a$ that was compound heterozygous for this and the known mutation Q660E. (A) Pedigree of the affected family. (B) Sequence analysis of exon 8 revealing heterozygosity for an A to $G$ transition at nucleotide 1274 which results in an amino acid exchange from glycine to serine at codon 425. (C) Restriction analysis of exon 8 (fragment 8B) with Ddel. The mutation creates a restriction site in the $480 \mathrm{bp}$ fragment, which is demonstrated by the two fragments of 322 and $158 \mathrm{bp}$; $\mathrm{C} 1$, undigested control amplicon; C2, digested control amplicon; ?, not analysed.

encoded by exons 8,9 and 10 is thought to be the catalytic centre of the TPO protein and several deleterious mutations in these exons have been reported $(5-7,11,12,15)$. The missense mutation N425S described here also falls within this domain. An acidic to neutral amino acid change is likely to influence the electron transfer environment and consequently the enzymatic activity of the protein. Besides the membrane spanning region encoded by exon 15 (7), little is known about the carboxyl terminus of TPO, where the relationship between function and structure is poorly understood. Mutations in this area have been reported in several patients with severe thyroid function $(3,5,7,9,12-15)$. The region encoded by exon 14 bears significant similarities to the epidermal growth factor (EGF)-like potential calcium binding domain (15), where there are three disulphide bonds, one of which is formed
$[1978 \mathrm{C}>\mathrm{G}]+[=][=]+[2748 \mathrm{G}>\mathrm{A}]$

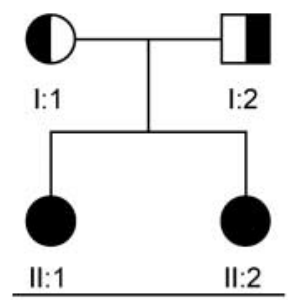

$[1978 \mathrm{C}>\mathrm{G}]+[2748 \mathrm{G}>\mathrm{A}]$

B

$\begin{array}{lllll}\text { C } & \text { II:1 } & \text { II:2 } & \text { I:1 } & \text { I:2 }\end{array}$

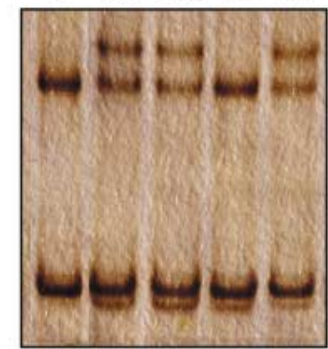

C
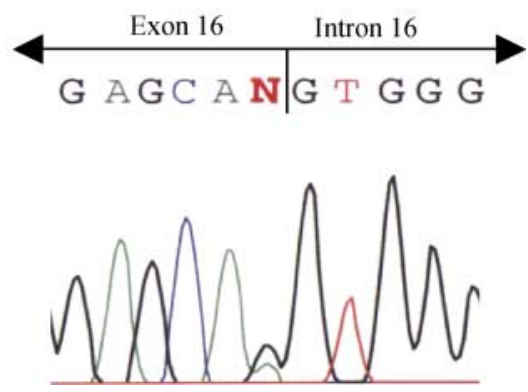

Figure 2 Novel heterozygous mutation in exon 16 (2748G > A) found in two siblings of family 10 that were compound heterozygotes for this and the known mutation Q660E. (A) Pedigree of the affected family. (B) SSCA of exon 16 showing the altered migratory pattern in both patients and in their father. (C) Sequence analysis revealing a $\mathrm{G}$ to $\mathrm{A}$ transition at nucleotide 2748 , silent at amino acid level but predictably affecting splicing.

between residues $\mathrm{C}^{825}$ and $\mathrm{C}^{838}$. The latter is precisely the residue which is altered in the novel mutation described here (C838S). The substitution of cysteine by serine disables the formation of the disulphide

Table 3 Comparison of amino acid sequences among various peroxidases coincident with mutations N425S and C838S.

\begin{tabular}{|c|c|c|}
\hline Mutant TPO & $K A L S^{425} A H W$ & GRT S ${ }^{838} \vee D S$ \\
\hline $\begin{array}{l}\text { Human TPO (17) } \\
\text { Pig TPO (22) } \\
\text { Mouse TPO (23) } \\
\text { Rat TPO (24) } \\
\text { Human MPO (25) } \\
\text { Human LPO (26) } \\
\text { Bovine LPO (26) } \\
\text { Human EPO (27) }\end{array}$ & 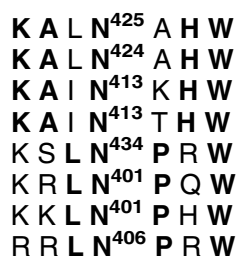 & 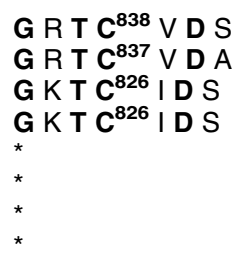 \\
\hline
\end{tabular}

${ }^{*}$ No $\mathrm{C}^{838}$ counterpart found in these peroxidases. Highly conserved amino acids are expressed in bold. 
bond and may thus disrupt the tertiary structure of the EGF-like potential calcium-binding domain. The novel mutation S131P, identified in exon 5, is likely to disrupt the potential glycosylation site at N129 (29), since the acceptor sequence required for N-glycosylation, namely N-X-S/T is modified to N-X-P. Studies have shown that $\mathrm{N}$-glycans play an essential role in the correct folding, intracellular trafficking and activity of TPO (30). The novel mutation identified in exon $16(2748 \mathrm{G}>\mathrm{A})$ is located at position -1 of the $5^{\prime}$ (donor) consensus splice site. Krawczak et al. (28) have reported a $97 \%$ consensus value for this residue in a similar sequence context. The GENSCAN program (31), that is designed to predict complete gene structures in genomic sequences, attributes a log-odds score of -20 for splicing with this base change, providing further evidence that the mutation abolishes splice site recognition. In all four cases, cosegregation analyses were consistent with a causal nature of the new mutations. Moreover, they were not detected in 100 healthy controls (200 alleles), as opposed to the hitherto undocumented polymorphism $180-47 \mathrm{~A}>\mathrm{C}$, which was found in $19 \%$ of the normal control alleles.

\section{General remarks}

In the 13 patients with TPO mutations, the most prevalent mutation was Q660E, previously reported in a Brazilian patient (10). It was found in a homozygous state in patient 6 and in compound heterozygosity in patients 3a, 3b, 4a, 10a and 10b. A similar prevalence was noted for the 1183_1186dupGGCC mutation (six alleles of the 13 patients with TPO mutations), also reported to be the most prevalent among Dutch patients (11). The severity of these two mutations is evident in family 3 where the older sibling $3 a$, who had not received L-thyroxine therapy, was severely affected with mental retardation. In the same line of reasoning, one may speculate that the novel predictive splice mutation described here $(2748 \mathrm{G}>\mathrm{A})$ is somewhat milder, since, in contrast with the other patients, neither affected sibling in family 10 presented goiter. Analysis of human TPO mRNA in these patients would help to elucidate the consequence of the splicing error (exon skipping and/or resort to cryptic splice sites, and resulting reading frame). This is the first molecular characterisation ever performed in a cohort of Portuguese $\mathrm{CH}$ patients in order to establish the aetiology of $\mathrm{CH}$ due to a dyshormonogenic defect. The exceptionally large proportion of patients found to have TPO mutations (approximately $24 \%$ of our sample) justifies the implementation of routine molecular testing in our $\mathrm{CH}$ neonates, with immediate benefits in terms of counselling and monitoring of future pregnancies, and with the foreseeable future benefit of aetiologybased differential treatment.

\section{Acknowledgements}

The authors would like to thank the families who gave their consent and collaborated in this study and the staff of the Neonatal Screening Laboratory for providing the original screening data of the patients. This work was supported by the Comissão de Fomento da Investigação em Cuidados da Saúde of the Portuguese Ministry of Health (project no. 163/99, Edital no. 898/98).

\section{References}

1 Relatório de Actividades em 2003, do programa Nacional de Diagnóstico Precoce. Instituto de Genética Médica Dr. Jacinto de Magalhães. (www.diagnosticoprecoce.org/divulgacao.htm).

2 Macchia PE, de Felice M \& di Lauro R. Molecular genetics of congenital hypothyroidism. Current Opinion in Genetic Development $19999289-294$.

3 Abramowicz MJ, Targovnik HM, Varela V, Cochaux P, Krawiec L, Pisarev MA, Propato FV, Juvenal G, Chester HA \& Vassart G. Identification of a mutation in the coding sequence of the human thyroid peroxidase gene causing congenital goiter. Journal of Clinical Investigation 199290 1200-1204.

4 Bikker H, den Hartog MT, Baas F, Gons MH, Vulsma T \& de Vijlder JJ. A 20 basepair duplication in the human thyroid peroxidase gene results in a total iodide organification defect and congenital hypothyroidism. Journal of Clinical Endocrinology and Metabolism $199479248-252$.

5 Bikker H, Vulsma T, Baas F \& de Vijlder JJM. Identification of five novel inactivating mutations in the human thyroid peroxidase gene by denaturing gradient gel electrophoresis. Human Mutation $199569-16$.

6 Bikker H, Waelkens JJ, Bravenboer B \& de Vijlder JJ. Congenital hypothyroidism caused by a premature termination signal in exon 10 of the human thyroid peroxidase gene. Journal of Clinical Endocrinology and Metabolism 199681 2076-2079.

7 Bikker H, Baas F \& de Vijlder JJM. Molecular analysis of mutated thyroid peroxidase detected in patients with total iodide organification defects. Journal of Clinical Endocrinology and Metabolism $199782649-653$.

8 de Vijlder JT, Ris-Stalpers C \& Vulsma T. Inborn errors of thyroid hormone biosynthesis. Experimental Clinical Endocrinology and Diabetes $1997 \mathbf{1 0 5} 32-37$.

9 Kotani T, Umeki K, Yamamoto I, Maesaka H, Tachibana K \& Ohtaki S. A novel mutation in human thyroid peroxidase gene resulting in total organification defect. Journal of Endocrinology $1999160267-273$.

10 Santos CL, Bikker H, Rego KGM, Nascimento AC, Tambascia M, de Vijlder JJM \& Medeiros-Neto G. A novel mutation in TPO gene in goitrous hypothyroid patients with iodide organification defect. Clinical Endocrinology 199951 165-172.

11 Bakker B, Bikker H, Vulsma T, de Randamie JS, Wiedijk BM \& de Vijlder JJM. Two decades of screening for congenital hypothyroidism in the Netherlands: TPO gene mutations in total iodide organification defects (an update). Journal of Clinical Endocrinology and Metabolism $2000 \mathbf{8 5}$ 3708-3712.

12 Ambrugger P, Stoeva I, Biebermann H, Torresani T, Leitner C \& Gruters A. Novel mutations of thyroid peroxidase gene in patients with permanent congenital hypothyroidism. European Journal of Endocrinology $2001 \mathbf{1 4 5} 19-24$.

13 Umeki K, Kotani T, Kawano J, Suganuma T, Yamamoto I, Aratake Y, Furujo M \& Ichiba Y. Two novel missense mutations in thyroid peroxidase gene, R665W and G771R, result in localization defect and cause congenital hypothyroidism. European Journal of Endocrinology $2002 \mathbf{1 4 6} 491-498$.

14 Niu DM, Hwang B, Chu YK, Liao CJ, Wang PL \& Lin CY. High prevalence of a novel mutation (2268 insT) of the thyroid 
peroxidase gene in Taiwanese patients with total iodide organification defect, and evidence for a founder effect. Journal of Clinical Endocrinology and Metabolism $2002874208-4212$.

15 Wu JY, Shu SG, Yang CF, Lee CC \& Tsai FJ. Mutation analysis of thyroid peroxidase gene in Chinese patients with total iodide organification defect: identification of five novel mutations. Journal of Endocrinology 2002172 627-635.

16 Kimura S, Kotani T, Mcbride OW, Umeki K, Hirai K, Nakayama T \& Ohtaki S. Human thyroid peroxidase: complete cDNA and protein sequence, chromosome mapping, and identification of two alternative spliced mRNAs. PNAS 198784 5555-5559.

17 Endo Y, Onogi S, Umeki K, Yamamoto I, Kotani T, Ohtaki S \& Fujita T. Regional localization of the gene for thyroid peroxidase to human chromosome $2 \mathrm{p} 25$ and mouse chromosome 12C. Genomics $199525760-761$.

18 Fujiwara H, Tatsumi K, Miki K, Harada T, Miyai K, Takai S \& Amino N. Congenital hypothyroidism caused by a mutation in the $\mathrm{Na}+/ \mathrm{I}$ - symporter. Nature Genetics 199716 124-125.

19 Coyle B, Reardon W, Herbrik JA, Tsui LC, Gausden E, Lee J, Coffey R, Grueters A, Grossman A, Phelps PD, Luxon L, Kendall-Taylor P, Scherer SW \& Trembath RC. Molecular analysis of PDS in Pendred syndrome. Human Molecular Genetics 19987 $1105-1112$.

20 Moreno JC, Bikker H, Kempers MJ, Trotsenburg P, Baas F, de Vijlder JJM, Vulsma T \& Ris-Stalpers C. Inactivation mutations in gene for thyroid oxidase 2 (THOX2) and congenital hypothyroidism. New England Journal of Medicine 2002347 95-102.

21 Miller SA, Dykes DD \& Polesky HF. A simple salting out procedure for extracting DNA from human nucleated cells. Nucleic Acids Research 1988161215.

22 Magnusson R, Gestautas J. Taurog A \& Rapoport B. Molecular cloning of the structural gene for porcine thyroid peroxidase. Journal of Biological Chemistry 1987262 13885-13888.

23 Kotani T, Umeki K, Yamamoto I, Takeuchi M, Takeuchi S, Nakayama T \& Ohtaki S. Nucleotide sequence of the cDNA encoding mouse thyroid peroxidase. Gene 1993123 289-290.
24 Derwahl M, Seto P \& Rapoport B. Complete nucleotide sequence of the cDNA for thyroid peroxidase in FRTL5 rat thyroid cells. Nucleic Acids Research 1989178380.

25 Johnson KR, Nauseef WM, Care A, Wheelock MJ, Shane S, Hudson S, Koeffler HP, Selsted M, Miller C \& Rovera G. Characterization of cDNA clones of human myeloperoxidase: predicted amino acid sequence and evidence for multiple mRNA species. Nucleic Acids Research 198715 2013-2028.

26 Dull T, Oyeda C, Strosberg D, Nedwin G \& Seilhamer J. Molecular cloning of cDNAs encoding bovine and human lactoperoxidase. DNA and Cell Biology 19901 499-509.

27 Sakamaki K, Tomonaga M, Tsukui K \& Nagata S. Molecular cloning and characterization of chromosomal gene for human eosinophil peroxidase. Journal of Biological Chemistry $1989 \mathbf{2 6 4}$ $16828-16836$.

28 Krawczak M, Reiss J \& Cooper D. The mutational spectrum of single base-pair substitutions in mRNA splice junctions of human genes: causes and consequences. Human Genetics 1992 $9041-54$.

29 Taurog A. Hormone synthesis: thyroid iodine metabolism. In Werner and Ingbar's The Thyroid, edn 8, part 1, ch. 4, pp 63-64. Eds LE Braverman \& RD Utiger. Philadelphia: Lippincott Williams \& Wilkins, 2000.

30 Fayadat L, Niccoli-Sire P, Lanet J \& Franc JL. Human thyroperoxidase is largely retained and rapidly degraded in the endoplasmic reticulum. Its $\mathrm{N}$-glycans are required for folding and intracellular trafficking. Endocrinology 1998139 4277-4285.

31 Burge CB. Modeling dependencies in pre-mRNA splicing signals. In Computational Methods in Molecular Biology, pp 127-163. Eds S Salzberg, D Searls \& S Kasif. Amsterdam: Elsevier Science, 1998.

Received 28 June 2004

Accepted 8 October 2004 